\title{
コロイド分散系に見られるさまざまな誘電挙動
}

一一相界面での電荷蓄積による誘電緩和現象の意味と実例

\author{
花井哲也 \\ 京都大学化学研究所 611 宇治市五ケ庄 \\ (1990年 8 月 16 日 受理)
}

\section{Dielectric Characteristics Found in Colloidal Disperse Systems}

\author{
Tetsuya HANAI \\ Institute for Chemical Research, Kyoto University \\ Gokashou, Uji, Kyoto 611
}

(Received August 16, 1990)

\begin{abstract}
分子溶液，すなわち分子均質混合系と対比して言うならば, コロイド分散系とは, 同種分子が集団を形成 して不均質に混合した状態であると言えよう。ての分子集合体が或る程度大きくなると，巨視的な相の概念 を持つようになる。したがってコロイド分散系は, 相界面の濃密な状態である。

コロイドの粗大分散系のさまざまな誘電特性は，乙の相界面・相表面の存在に起因するすのである。これ らの誘電特性を解析すると,コロイド分散系を構成する成分相の誘電率・導電率や構造に関する知見を得る ことができる。
\end{abstract}

\section{1.コロイド分散系の誘電挙動の典型的一例}

分子溶液の代表として, $\mathrm{KCl}$ 水溶液を, またコロイド 系の典型的な系として, 油中水滴 (W/O) エマルション を, 採り上げ，それらの誘電率 $(\varepsilon)$, 導電率 $(\kappa)$ の測定 周波数 $(f)$ による変化工合を, 図 1 亿示す。見ればすぐ 判るように，均質混合系の $\mathrm{KCl}$ 水溶液の $\varepsilon, \kappa$ は周波数 $(f)$ によらず, 一定の值であるが, 不均質混合系の W/O エマルションでは, $\varepsilon, \kappa$ のいずれあ周波数 $(f)$ に対し て, 著しく変化している。乙の周波数変化の挙動を誘電 緩和現象という。

この現象は一体何を意味するのか。一般に，コロイド 分散系は濃密に相界面を内蔵していて, ての相界面に 電荷の溜る程度が変るととが誘電緩和現象の原因とな る11。それで誘電率・電気容量の意味を説明して，まず 平面状の相界面の電荷停留によるいろいろな変化を考察 しょう。

\section{2. 電気容量・誘電率とは何か}

図 2 のような, 面皘 $(S)$, 間隔 $(d)$ で誘電物質の詰

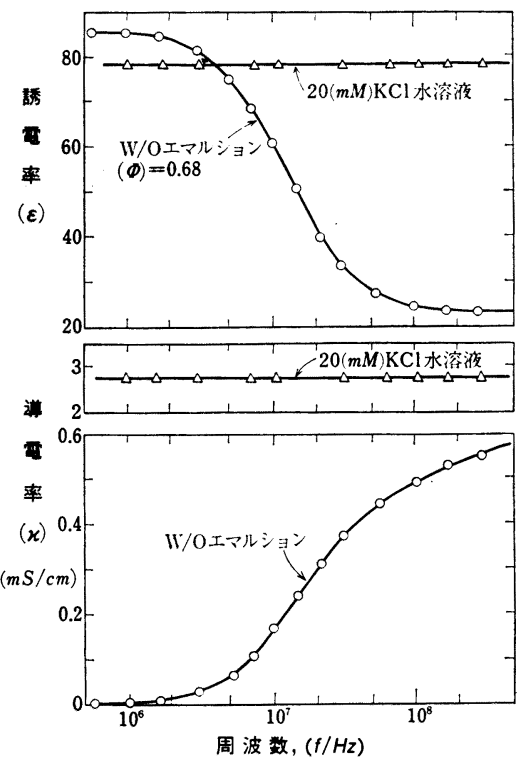

図 1 分子溶液 $-\Delta$ 一, コロイド分散系 $-O-$ との, 誘電率 $\varepsilon$, 導電率 $\kappa$ の比較。 


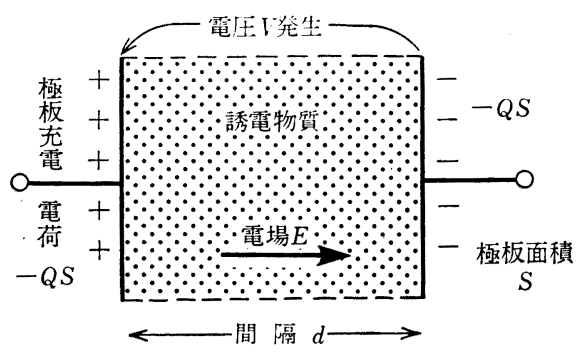

$$
\begin{aligned}
& \text { 電気容量 } C=\frac{Q S}{V} \\
& \text { 誘電 承 } \varepsilon=\frac{C}{C_{0}}
\end{aligned}
$$

図 2 平行板コンデンサーの充電による電気容量 $C$, 誘電率 $\varepsilon$ の説明。

った平行板コンデンサーに $1 \mathrm{~cm}^{2}$ 当り $(Q)$ の電荷を与 える,すなわち $Q S$ だけ充電すると, 両極板の間の誘電 物質内に電場 $E$ を生じる。そして両極板間には, $E \times d$ $=(V)$ だけの電圧を発生する。この状態で, 電気容量 $(C) \equiv Q S / V$ と定義する。両極板の間に誘電物質が無く て，真空のときの量を $\left(E_{0}\right),\left(V_{0}\right),\left(C_{0}\right)$ などと記す。ま た(比)誘電率 $\varepsilon \equiv C / C_{0}$ と定義する。 $C_{0}=Q S / V_{0}$ である。 実際に同じ充電電荷 $Q S$ を付与すると, 真空での電圧 $V_{0}$ よりも誘電物質挿入時の電圧 $V$ は小さい。 $V<V_{0}$ ゆえに $C>C_{0}, \varepsilon>1$ となる。

\section{3. 最も簡単な平面状相界面の例}

この例として, 図 3 に示すような, イオンを通さない 高分子膜とイオンのよく動く水相とが平面状接触をして いる系を考えよう。困 3(A)のような二相結合系は, 困 3(B) のように誘電緩和現象を呈する。低周波で $C$ が

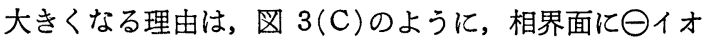
ンが，右極板面にやイオンが停留するためである。図 3 (C)の状態は, 充電電荷により形成される電場, 図 3

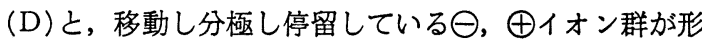
成する場合，図 3(E) と，に分けて考えられる。そして その総合された結果が図 3(F)のようになる。すなわち, 絶縁性 $\kappa_{f}=0$ の膜相内では, 極板充電電荷 $Q S$ による 電場がそのまま保たれ，導電性のある $\kappa_{w} \neq 0$ の水相内 では, 電場が消える。したがって, 外部から見ると, 図 3(G) のようであり，てれは図 3(A)の場合よりあずっ と小さい間隔のコンデンサーとしてふるまう。これが低 周波で電気容量が大きくなるからくりである。

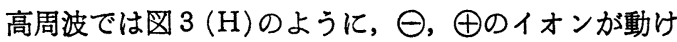
るほどの時間的余裕が無いので，イオン移動・分極を形 成できない。したがって，図 3 (B)の右端に見られるよ うに，電気容量は小さい值として見える。

要するに，相界面に可動電荷（イオン）が停留する
と, その停留電荷が作り出す電場が加算される。その結 果，見かけ上はコンデンサーの二極板が接近したかたち となり, 電気容量の増大となる。これが界面分極による 誘電率増大である。

\section{4. 水中のポリスチレン膜の系 ${ }^{2 \sim 4)}$}

図 4(A)のように, 水相一ポリスチレン膜一水相とい う系の交流下の誘電測定をすると, 四 4(B)のように, 周波数 $(f)$ の上昇につれて, 電気容量 $C$ は減少し, コンダクタンス $(G)$ は増大する。すなわち典型的な Debye 型誘電緩和を呈する。

困 4(C)には, 電圧を加えたときの, 低周波で水相内

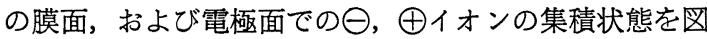
示してある。ポリスチレン膜表面にイオンが停留する。

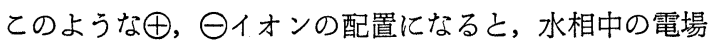
は打ち消されてしまい，零となる。膜内では，膜境界面

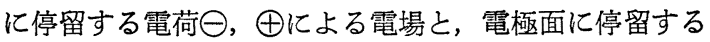

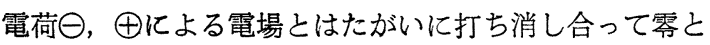
なり，極板充電の電荷十，一による電場だけがそのまま 有効に残る。したがって眓 4(D) に示したように，膜だ けをはさんだ狭い間隔の平行板コンデンサーとしてふる まう。これによって, 圀 4(B) の低周波 $\left(10^{2} \mathrm{~Hz}\right)$ での 大きな $\left(C_{l}\right)$ 值が形成されている。

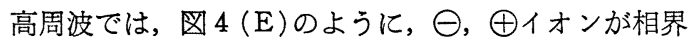
面や電極面まで移動する㗇がなくて, 水相内部で振動し ており，電荷の分離，すたわち分極を引きおこさない。 したがって，もとの平行板コンデンサーの広い間隔の電 気容量が, 困 $4(\mathrm{~B})$ の右端の小さい $\left(C_{h}\right)$ 值となってい る。

なお，図 $4(\mathrm{~B})$ で $C_{l}, C_{h},\left(G_{l}\right),\left(G_{h}\right)$ を実測結果か ら読みとると, 次式によって, 膜相 $(f)$, 水相 $(w)$ の 電気容量 $\left(C_{f}\right),\left(C_{w}\right)$ やコンダクタンス $\left(G_{f}\right),\left(G_{w}\right)$ が容易に算出できる。

$$
\begin{aligned}
& A \equiv\left[\left(1-\frac{G_{l}}{G_{h}}\right)^{-1}-\left(\frac{C_{l}}{C_{h}}-1\right)^{-1}\right]\left(\frac{C_{l}}{C_{h}}-1\right)^{\frac{1}{2}} \\
& Y_{f}=\frac{1}{2}-\frac{1}{2}\left\{1+\left(\frac{2}{(A)}\right)^{2}\right\}^{-\frac{1}{2}}, \\
& C_{f}=\frac{C_{h}}{\left(Y_{f}\right)}, \quad C_{w}=\frac{C_{h}}{1-Y_{f}}, \\
& A>0 \text { ならば, }
\end{aligned}
$$

$$
\left(X_{f}\right)=Y_{f}+\left[Y_{f}\left(1-Y_{f}\right)\left(\frac{C_{l}}{C_{h}}-1\right)\right]^{\frac{1}{2}},
$$

$A<0$ ならば,

$$
\begin{aligned}
& \left(X_{f}\right)=Y_{f}-\left[Y_{f}\left(1-Y_{f}\right)\left(\frac{C_{l}}{C_{h}}-1\right)\right]^{-\frac{1}{2}}, \\
& G_{f}=\frac{G_{l}}{X_{f}}, \quad G_{w}=\frac{G_{l}}{1-X_{f}}, \quad\left(f_{0}\right)=\frac{1}{2 \pi} \cdot \frac{G_{h}-G_{l}}{C_{l}-C_{h}},
\end{aligned}
$$


(A) 二相直列結合系

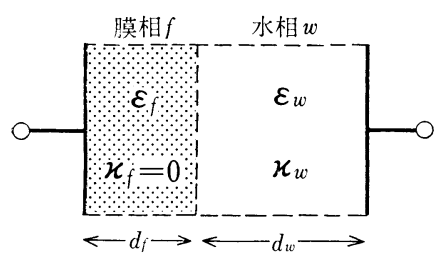

(C) 可動電荷の移動, 分極 (低周波)

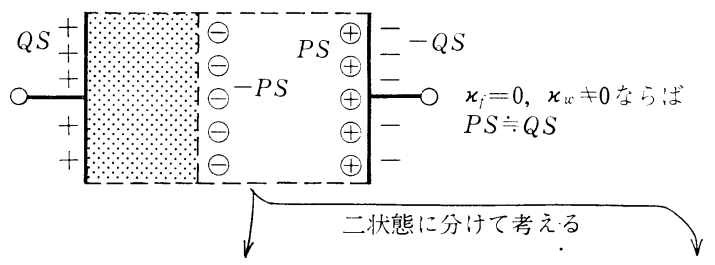

（D）充電電荷による電場

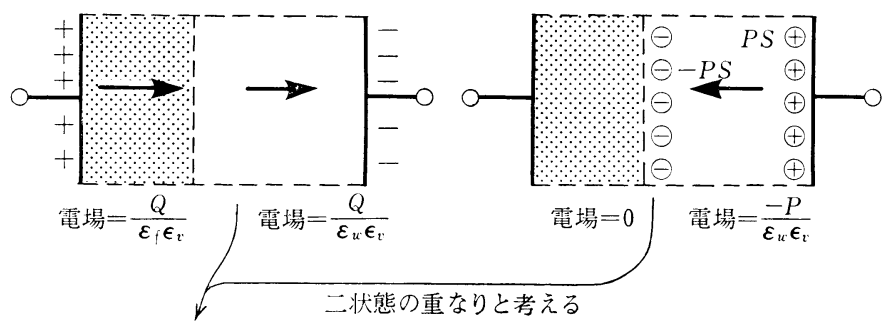

(F) 前記 (D)，(E)の重なった状態

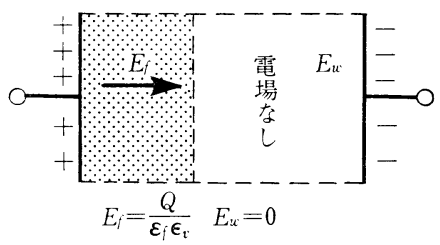

（G）外部から見える有効状態

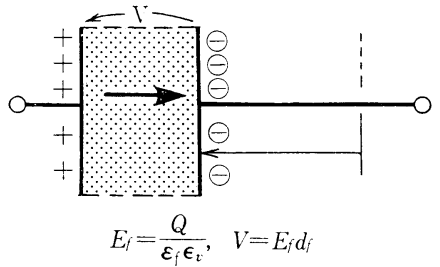

（B）結合系全体の誘電緩和

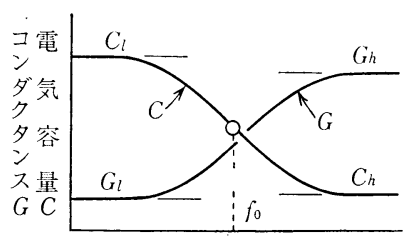

測定周波数, $f$
E) 移動し，分極したイオンによる電場
（H）高周波での電荷分布状態

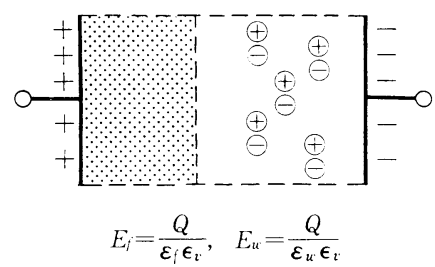

図 3 膜相・水相直列結合系での自由可動電荷(イオン)の動き之電場, 電位差の変化。

いろいろな濃度の $\mathrm{KOH}$ 水相中にあるポリスチレン 膜の系の誘電測定をすると, 図 4(B) と同じような誘電 緩和の結果を得る。乙の実測結果の $C_{l}, C_{h}, G_{l}, G_{h}$ などを上記の式に代入して, 膜の值 $C_{f}, G_{f}$, 水相の值 $C_{w}, G_{w}$ 在算出できる。それらの結果は, 図 5 のように なった。膜の容量 $C_{f}$ は水相の $\mathrm{KOH}$ 濃度によらず,一

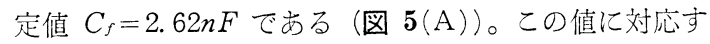
る膜物質の誘電率は $\left(\varepsilon_{f}\right)=2.67$ となり, ポリスチレン
材料の值として妥当である。

ところがポリスチレン膜の導電率 $\left(\kappa_{f}\right)$ は, 四 $5(C)$ に見られるように，水相の $\mathrm{KOH}$ 濃度に比例している。 水相の $\left(\kappa_{w}\right)$ も $\mathrm{KOH}$ 濃度に比例しているから (図 5 (B)), 比 $\kappa_{f} / \kappa_{w}$ を採机ば, 図 5(D) の上うに, $\mathrm{KOH}$ 濃度によらず一定值になる。また， $\kappa_{f} / \kappa_{w} \simeq 10^{-4}$ の程度 の大きさである。てれらを総合して考えると，ポリスチ レン膜には, 膜全面積の $1 / 10^{4}$ 程度の面積の機械的小穴 
（A）水中の膜

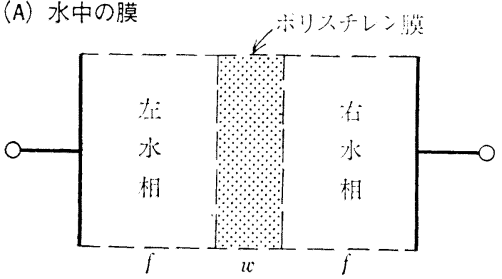

(C) 低周波で

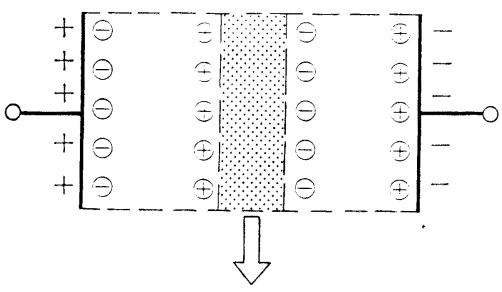

（D）低周波での実効状態

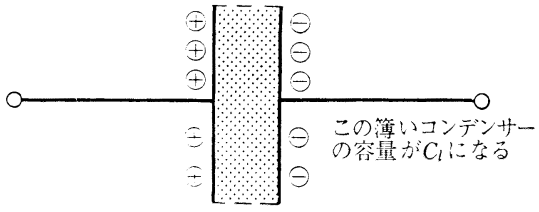

(E) 高周波で

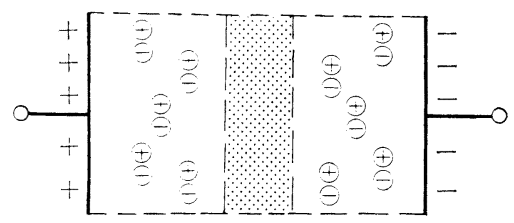

（B）誘電観測結果
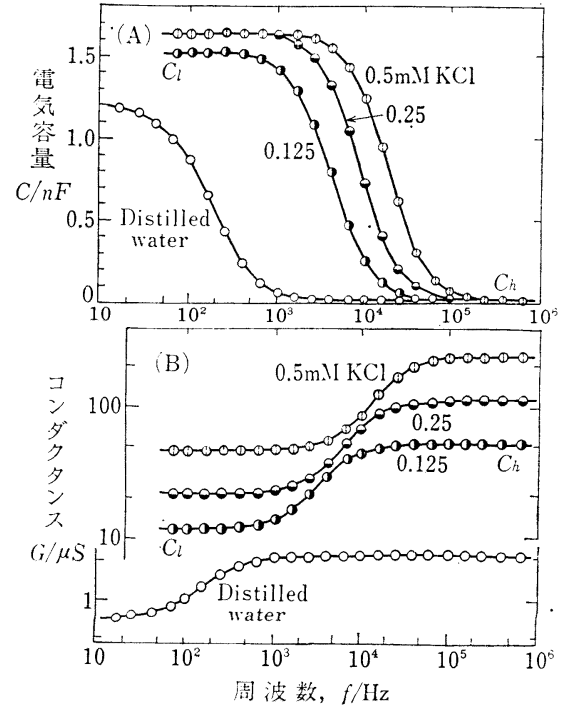

$$
\sqrt{y}
$$

(F) 構成成分相の等価回路

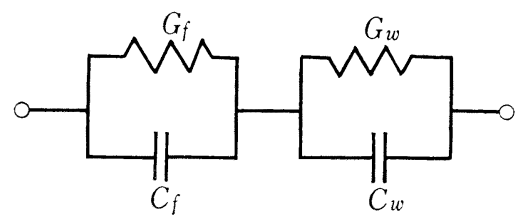

図 4 水中ポリスチレン膜の系の誘電緩和と相界面イオン停留（分極）による説明。

があいていて，この穴に隣接水相からイオン水溶液が浸 み込み，乙礼が，膜のコンダクタンスとなっているのだ ろうと考えられる。このように水相一膜相の境界面に停 留する電荷から, 誘電緩和を生じ, この测定結果を解析 すると，膜の内部構造まで推祭できるということにな る。

\section{5. 油中水滴 $(\mathbf{W} / \mathbf{O})$ 型エマルションの系 ${ }^{5 \sim 12}$}

この W/O エマルションの実測例は, すでに図 1 で紹 介してある。すなわちコロイド分散系, 不均質系の一典 型であり，誘電緩和が顕著に観測される。今までの， 「相界面に電荷停留」と「竦電誘和」との因果関係を想 い出すならば「W/Oエマルションの水一油境界面に電 荷停留」ということを容易に想像できよう。

図 6 に $/ O$ エマルションの界面分極と, それに伴う 電気容量增大の状況を図解してある。W/O エマルショ
ン試料の満たされた平行板コンデンサーに充電すると,

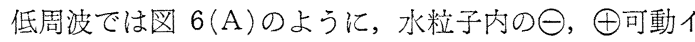
オンは充分に移動して, 水粒子内で電気分極を生じる。 そして, 水粒子内部の電場が無くなるまで可動イオンが 動いて, 平衡状態になる。その総合結果は, あたかも図 6(B) のように, 連続油相に対応する絶縁油相が左・右

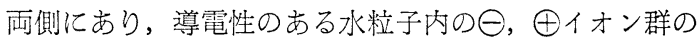
分離状態が，中央の $\ominus ， \oplus の$ 分極した水相で表わされる という対応状態を執る。

この四 6(B)の状態は，(C) と (D)の二状態に分けて 考えるのが便利である。すなわち，因 6(C)の極板充電 電荷により形成される電場配置と, 図 6(D)の移動・分 極したイオン群による電場配置とである。こしてての (C)，(D) 二状態の重なりとして，図 6(E)が出来ると 考えると, 中央の水相部分は電場零で, 而端 (外側連続 相にあたるもの）にのみ電場がかかったような構成とな 

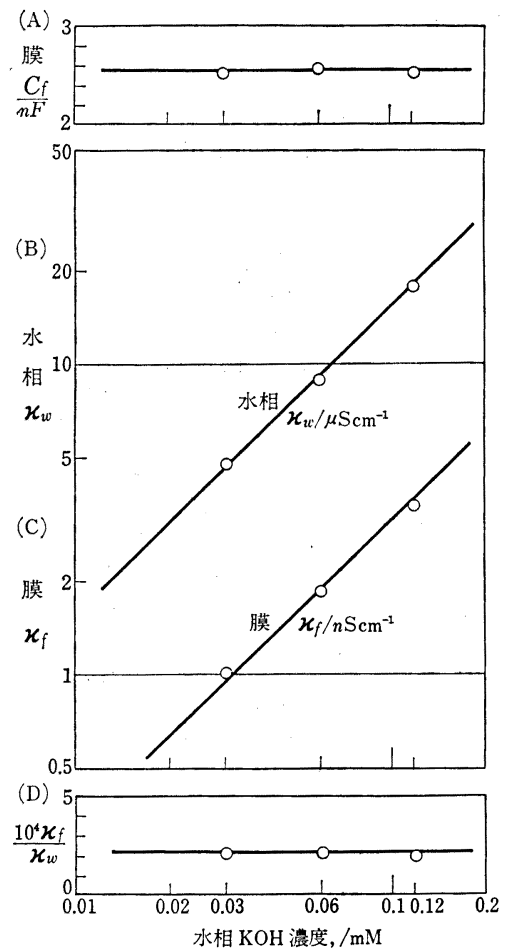

図 5 水中ポリスチレン膜の電気容量 $C_{f}$, 導電率 $\kappa_{f}$ などの挙動。

り，それは結局，困 6(F)のような油相コンデンサー二 個の直列系のようなもの之考えられる。すなわち，間隔 の狭いコンデンサーに相当し, 大きな電気容量 $C_{l}$ (図 6 (H)) として観測される。

高周波では, 困6 (G) 亿示すように $\Theta$, $\oplus$ 可動イオン 群は相界面まで動けるほどの時間的余裕が無いから, 水 粒子内で分極に至らず，振動している。その結果は始め の広い間隔の平行板コンデンサーの小さい電気容量 $C_{h}$ を観測することになる。

電場の理論考察の結果として得られた $\mathrm{W} / \mathrm{O}$ エマル ションの式は,

水粒子の体積分率（体積割合）

$$
(\Phi)=1-\left(\frac{\varepsilon_{a}}{\varepsilon_{l}}\right)^{\frac{1}{3}},
$$

\section{連続外水相の導電率}

$$
\left(\kappa_{a}\right)=\left(\kappa_{l}\right)(1-\Phi)^{3},
$$

\section{水粒子の誘電率}

$$
\left(\varepsilon_{i}\right)=\varepsilon_{a}+\frac{\left(\varepsilon_{h}\right)-\varepsilon_{a}}{1-\left(\frac{\varepsilon_{h}}{\varepsilon_{l}}\right)^{\frac{1}{3}}}
$$

水粒子の導電率

$$
\left(\kappa_{i}\right)=\left(\kappa_{h}\right) \frac{1-\frac{1}{3}\left(2+\frac{\varepsilon_{a}}{\varepsilon_{h}}\right)\left(\frac{\varepsilon_{h}}{\varepsilon_{l}}\right)^{\frac{1}{3}}}{\left[1-\left(\frac{\varepsilon_{h}}{\varepsilon_{l}}\right)^{\frac{1}{3}}\right]^{2}},
$$

である。四 1 に引用した W/O エマルションの実測值 $\varepsilon_{l}=85.4, \varepsilon_{h}=22.8 \kappa_{l}=84.7 n S \mathrm{~cm}^{-1}, \kappa_{h}=507 \mu S \mathrm{~cm}^{-1}$, などを前記の式に代入して数值計算すると， $\Phi=0.678$ ， $\kappa_{a}=2.82 n S \mathrm{~cm}^{-1}, \quad \varepsilon_{i}=58.9, \kappa_{i}=2.18 \mathrm{mS} \mathrm{cm} \mathrm{cm}^{-1}$ などの 成分相のいろいろな性質を表わす量の値が得られる。

\section{6. 二種類の水相にはさまれた膜の系 ${ }^{12}$}

図 7(A) のように, 蒝溜水 - 膜 $-\mathrm{KCl}$ 水溶液という ような三相の直列結合の系全体の誘電測定をすると，困 7 (B)のように, 明らかに二個の誘電緩和が観測される。

この二個の誘電紱和の起因を困解で説明しよう。低周 波では図 7(C)のように, 膜の両面の外側に自由可動1 オン $\oplus, \ominus$ 充分に停留する。したがって左・右両水相

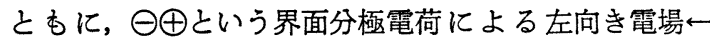

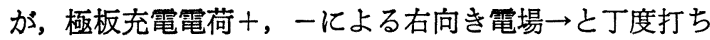
消し合う。その結果, 左・右水相内は電場零となり, 四 7 (D) のように，膜内だけに極板充電電荷十，一による 電場が残る。この状態は，膜だけの，間隔の狭いコンデ ンサーのようにふるまう。乙れが低周波での大きな $C_{l}$ 值となって観測される。

中周波では, 因 7(E)のように, 蒸留水中には可動1

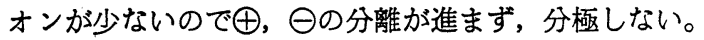
それで極板充電による電場を減らさない。右水相はイオ

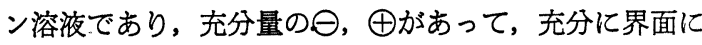
停留し分極する。したがって右水相内は電場零になる。 それらの結果は図 7(F)のように, 膜だけの (D)の場合 よりあ少し極板間隔の広がったコンデンサーとしてふる まうことになる。この状態が中程度の大きさの $\left(C_{m}\right)$ 值 として観測される。

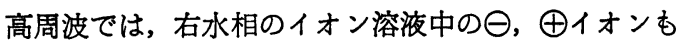
界面に停留する㗇がない。すなわち分極しない。その結 果は, 困 7(G)のように，広い間隔のコンデンサーとし てふるまい，小さい $C_{h}$ 值として観測される。

\section{7. 球殼状構造の䜿濁系 ${ }^{13 \sim 17)}$}

このような系としては, 人工系ではマイクロカプセル があり, 天然の系としては, 多くの生物紐胞類がての球 殾構造を採っている。

マイクロカプセルは図 8(A)のようなポリスチレンの 球殼である。この球凯状粒子の䅫濁系を誘電測定する 之, 因 8(B)のように, P一緩和，Q一緩和と名付ける 二個の誘電緩和が観測される。 
(A) 淌中水激分散系

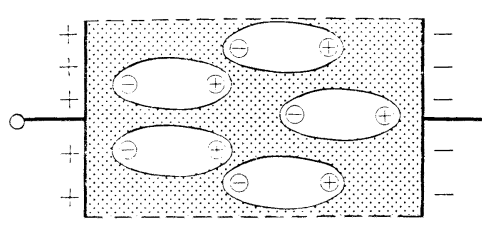

（B）低周波で
二状態に分けて考える

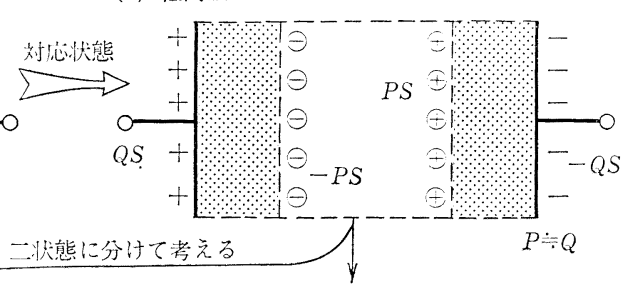

(D) 移動し, 分極したイオンによる電場

（C）充雮電荷による電場
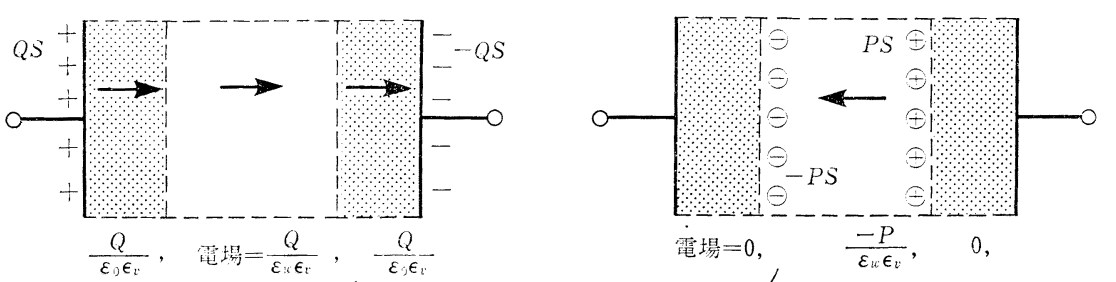

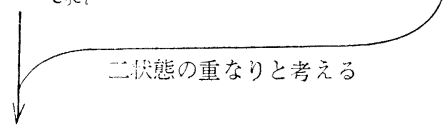

(E) 前記(C), (D)の重なった状態

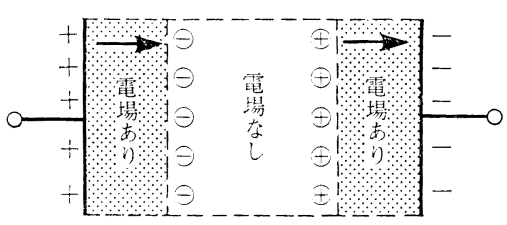

(G) 高思波で

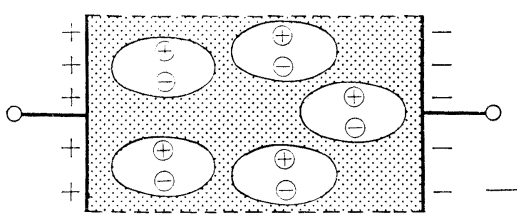

元のままの間隔の広い

コンデンサーの容量がChになる
（F）低周波での実効䔸態

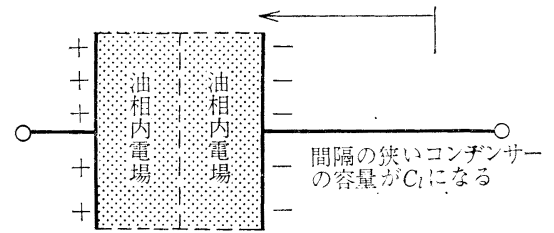

(H) 誘電観測結果

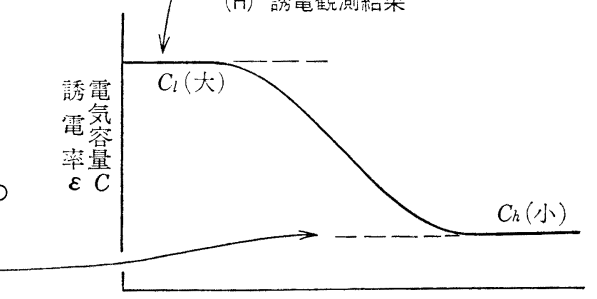

测定周波数, $f$

図 $6 \mathrm{~W} / \mathrm{O}$ エマルションの界面分極による誘電緩和現象の困解説明。

前項 6 において, 平面膜と左・右二水相の系で二個の 䛿電緩和を生じたととを考えると，乙の図 8(A)の系 は，球款という膜と外・内の二水相から成る系であるか ら, 二個の誘電緩和の存在むうなずける。

球殼状粒子系の誘電緩和二個の発現機構を図 8 亿図解 ずる。低周波では, 図8 (C)のように可動イオン $\ominus, \oplus$ が相界面まで充分に動き，界面分極を生じている。した がって外・内水相ともに電場が零になり，水相部分は短 絡したようになる。すなわち, 困8 (D)のように半球款 という狭い間隔のコンデンサーが 2 個直列に並んだ状態 にあるから，低周波では大きな電気容量 $C_{l}$ が観測され
る。

中周波では, 四 8(E)のように, 外水相が蒸留水であ ると, 可動イオン $\oplus, \ominus$ 移動, 分極が起きない。可動 イオン濃度の高い内水相では $\oplus, \ominus か ゙$ 充分に相界面に停 留し，分極を形成する。すなわち，図 $8(F)$ に図解する ように球殼と外水相とを合わせた部分が，中程度間隔の コンデンサーとしてふるまう状態が中くらいの大きさの $C_{m}$ 值として観測される。

高周波では，図 8(G)のように，外・内水相いずれも $\oplus, \ominus$ インン動き得ないから, 分極が起きない。した がって, 外水相・球殼 ・内水相のすべてが直列に並んだ 
(A) 左·右水相が異なる水中膜の系

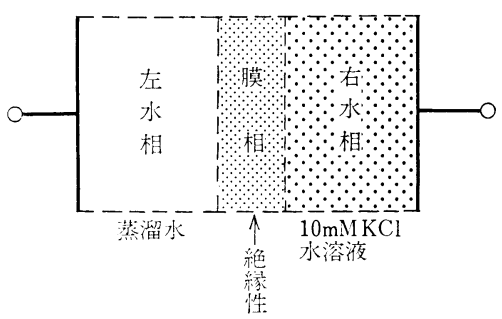

(E) 中周波て

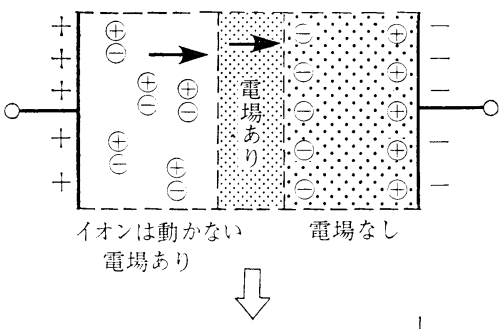

(F) 実効状態

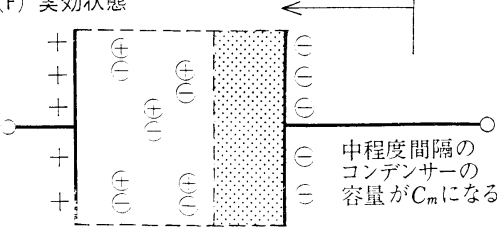

(G) 高周波で

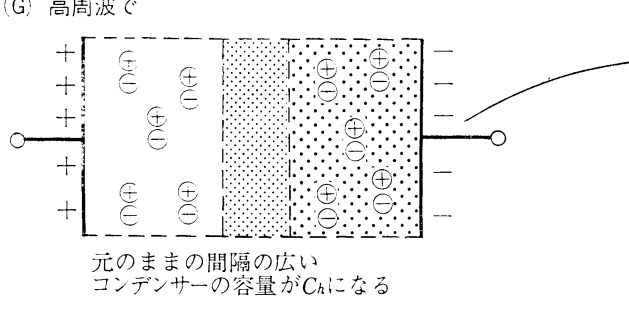

（C）低周波で

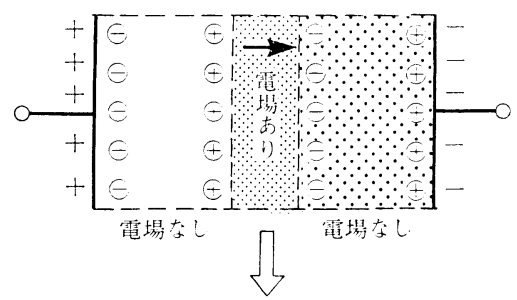

（D）低周波での実効状態

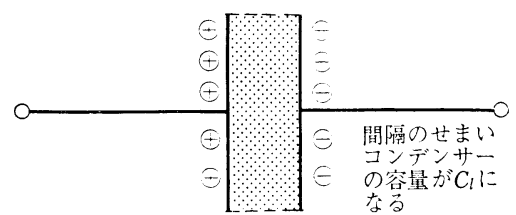

(B) 誘電観測結果, 二重緩和

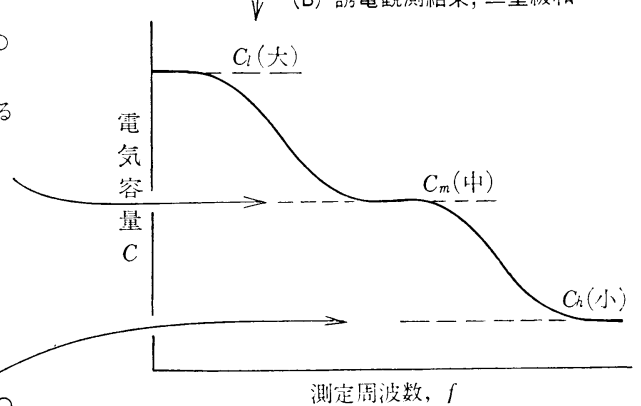

测定嘼波数, $f$

図 7 左・右水相が異なる水中膜の系の二重誘電緩和現象之困解説明。

広い間隔のコンデンサーとしてふるまう。との状態が小 さい電気容量 $C_{h}$ 值として観測される。

\section{8. まと め}

コロイド粗大分散系では，交流電場の下で，可動イオ ン $\oplus, \ominus$ ガ相境界面に停留すると，相の内部の電場を打 ち消して電場を零にしてしまう。これはその相を短絡し たかたちとなり，共存する他の相について間隔の狭いコ ンデンサーのような状況となる。それが大きい電気容量 值を呈することになる。高周波になると，乙れら可動イ オンの相界面停留がなくなり，分極が減り，電気容量の
減少になる。これら誘電緩和の全体の定量的解析を進め る之，成分相の大きさ，成分相の誘電率・導電率，さら に成分相の混合構造を知ることができる。それらの計算 のための数式は引用文献洋述されている1,3,4,10 13,17)。

\section{文献}

1) T. Hanai, H. Z. Zhang, K. Sekine, K. Asaka and K. Asami : Ferroelectrics 86, 191 (1988).

2) H. Z. Zhang, T. Hanai and N. Koizumi : Bull. Inst. Chem. Res., Kyoto Univ. 61, 265 (1983).

3) H. Z. Zhang, K. Sekine, T. Hanai and N. Koi- 
（A內·外水相が畋なる球凯系

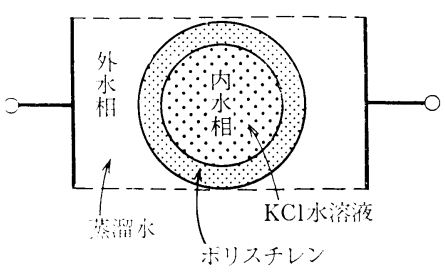

中周波で

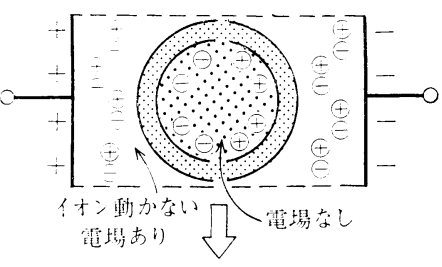

(F) 中周波での実効状熊
（C）低周波で

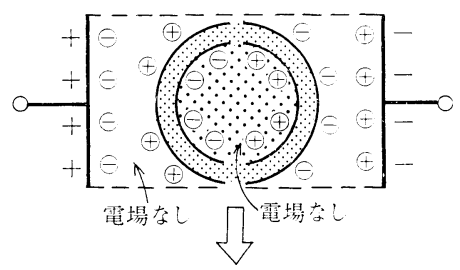

（D）低周波での実効状態
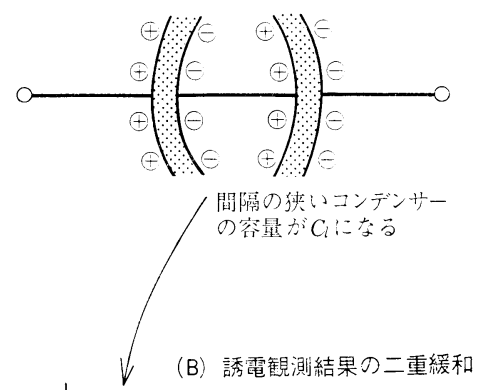

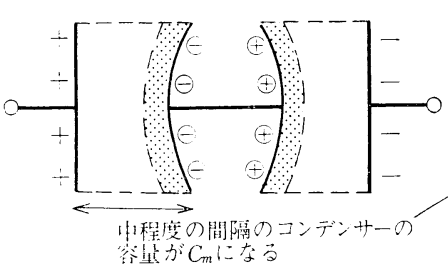

G) 高周波で

测定周波数, $f$

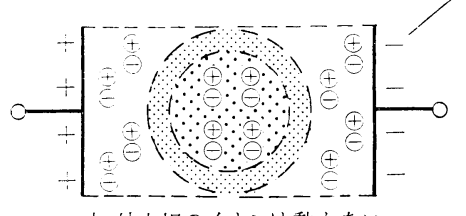

内外水相のイオンは動かない。 三相寸心゙て, 電場あり

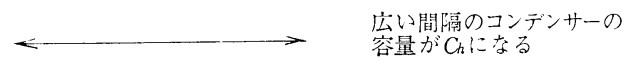

図 8 マイクロカプセル系の二重誘電緩和現象之困解説明。

zumi : Membrane 8, 249 (1983).

4) K. S. Zhao, K. Asaka, K. Sekine and T. Hanai : Bull. Inst. Chem. Res., Kyoto Univ. 66, 540 (1988).

5) T. Hanai : Kolloid Z. 175, 61 (1961).

6) T. Hanai : Kolloid Z. 177, 57 (1961).

7) T. Hanai : Bull. Inst. Chem. Res., Kyoto Univ. 39, 341 (1961).

8) T. Hanai and N. Koizumi : Bull. Inst. Chem. Res., Kyoto Univ. 54, 248 (1976).

9) T. Hanai and N. Koxzumi : Bull. Inst. Chem. Res., Kyoto Univ. 53, 153 (1975).

10) T. Hanai, T. Imakita and N. Koizumi : Colloid Polymer Sci. 260, 1029 (1982).
11) T. Hanai, A. Ishikawa and N. Koizumi : Bull. Inst. Chem. Res., Kyoto Univ. 55, 376 (1977).

12) T. Hanai, K. Sekine and N. Koizumi : Bull. Inst. Chem. Res. Kyoto Univ. 63, 227 (1985).

13) H. Z. Zhang, K. Sekine, T. Hanai and N. Koizumi : Colloid Polymer Sci. 261, 381 (1983).

14) H. Z. Zhang, K. Sekine, T. Hanai and N. Koizumi : Colloid Polymer Sci. 262, 513(1984).

15) T. Hanai, N. Koizumi and A. Irimajiri: Biophys. Struct. Mechanism 1, 285 (1975).

16) T. Hanai, K. Asami and N. Koizumi : Bull. Inst. Chem. Res., Kyoto Univ. 57, 297 (1979).

17) T. Hanai and K. Sekine: Colloid Polymer Sci. 264, 888 (1986). 